\title{
RISK-RETURN PERFORMANCES OF REAL ESTATE INVESTMENT FUNDS IN TURKEY INCLUDING THE COVID-19 PERIOD
}

\author{
Mehmet Emre ÇAMLIBEL (iD ${ }^{1,}$, Levent SÜMER (iD ${ }^{2}$, Ali HEPŞEN (iD ${ }^{3}$ \\ ${ }^{1}$ Department of Construction Management and Real Estate, Vilnius Gediminas Technical University, Vilnius, Lithuania \\ ${ }^{2}$ Faculty of Economics, Administrative and Social Sciences, Istinye University, Istanbul, Turkey \\ ${ }^{3}$ School of Business, Department of Finance, Istanbul University, Istanbul, Turkey
}

Received 04 June 2020; accepted 17 February 2021

\begin{abstract}
The purpose of this research is to give an insight into the Turkish real estate investment funds (T-REIFs) by comparing their risk-return performances with the main benchmark investment tool Istanbul Stock Exchange-100 (BIST-100) Index. This study evaluated the performance of T-REIFs in four different periods between January 2017 and December 2020 (2017m1-2017m12, 2018m1-2018m12, 2019m1-2019m12 and 2020m1-2020m12) including the Coronavirus Disease (Covid-19) period by applying the Sharpe and Treynor ratios. In a well-diversified portfolio both ratios give the same results, but in the presence of non-systematic risk and the portfolio is poorly diversified, the Treynor ratio is a better indicator than the Sharpe ratio. The findings of this study show that rankings of Sharpe and Treynor ratios may differ for each period. These results also support the fact that the portfolios of funds in the Turkish real estate market are not well diversified. By providing corporate tax exemptions, and by enabling the investors to diversify their investments and reduce their risks, real estate investment funds are important alternatives to direct real estate investments in Turkey. In that context, being one of the pioneer studies in this niche and a new topic in emerging markets, analyzing the return performances of T-REIFs and comparing them with the returns of the BIST-100 index is aimed to contribute to literature as well as provide insight to investors who may consider investing in the Turkish real estate capital market instruments.
\end{abstract}

Keywords: real estate investment funds, return performances, emerging markets, performance measurement, Sharpe ratio, Treynor ratio, Covid-19.

\section{Introduction}

Urbanization and industrialization have been important pioneers of the development of Turkey since the 1950s. Since then, the Turkish real estate and construction industries have been major and leading sectors in Turkey. Until 2001, the development of real estate projects was not very large, and the projects were limited to some mid-scale residential and commercial projects. After the economic crisis in 2001, parallel to the investment plans of the new government, the sizes, types, numbers and investment volumes of the real estate investments started increasing rapidly. As an emerging economy, the opportunities such as the increase in household income level, development of the retail market, the geopolitical location of Turkey that connects Europe, Central Asia and the Middle East and the need for urban transformation supported with new laws, regulations and incentives, attracted both the local and foreign investors as well as customers.
As a result, many large real estate investment companies were established; many international companies entered to Turkish real estate market, thousands of new residential units and hundreds of new shopping malls and commercial projects were constructed, sold and leased in a very short period. The rapid development of the industry made significant positive impacts on the economy but also brought serious problems together especially from a financing perspective. The traditional financing model which is based on the sell-finance-construct method did not meet the increasing demand for funding. Moreover, the companies used bank loans to finance their projects, and a rapid increase in interest rates in the last decade put many companies in serious financial problems. In that sense, for sustainable growth, it is important for the real estate investment and development companies in Turkey to understand the dynamic market conditions and needs, to utilize their assets efficiently, to reach alternative

*Corresponding author. E-mail: emre.camlibel@re-pie.com 
financing resources, to manage their costs and to increase their flexibility to match the changing environments. Real estate investments have a dependency on the regulations on land uses, financial institutions, legal transactions and cultural choices. Transparency and market efficiency may reduce risks, and the reduced costs of capital may allow for sustainable growth.

In that context, the Capital Market Board issued the real estate investment company (REIC) regulation in 1995 to bring transparency and deepness to real estate capital markets. Although the regulation provided important incentives such as corporate tax exemptions, the development of the REICs in Turkey remained very limited. In addition to the REIC regulation, CMB issued a new regulation for establishing real estate investment funds (REIFs) in 2014. General terms about the management of the fund, custody of the assets, valuation principles and conditions of investing in the fund are determined in (III-52.3) Communique on Real Estate Investment Funds (Capital Market Board [CMB], 2020).

From investors' point of view, political stability, ease of doing business, legal regulations, transparency, return rates, taxation and sustainability of the investments are important parameters while investing in a country. Aggarwal et al. (2003) investigated the investment criterion of the U.S. funds in emerging markets and stronger legal policies, accounting regulations and shareholder rights were found important factors. Jagongo and Mustwenje (2014) classified the factors that affect the decisions of individual investors as; reputation and positioning of the firms, expected earnings, profit, past performances of the firms, the price per share and prospect of the economy. In that sense, the regulations in the real estate industry need to respond to those expectations. Real estate investment funds seem to be an important investment tool that covers many long-term investors' decision criteria. A REIF does not have a legal entity and is established by portfolio management companies or real estate portfolio management companies that hold an operating license from $\mathrm{CMB}$. According to the regulation issued by CMB in 2014, real estate investment funds can manage portfolios comprised of the real estates and property rights, public and private debt instruments and joint-stock company shares founded in Turkey, including those in the privatization process, foreign public and private debt instruments and shares of joint-stock companies tradable within the framework of related laws, participation accounts, time deposits, investment fund units, repo and reverse repo transactions, certificates, warrants, lease and real estate certificates, settlement and custody bank money transactions, cash collaterals and premiums of derivative transactions, specially designed foreign investment instruments and loan participation notes deemed appropriate by the Board, other investment instruments deemed appropriate by the Board. Fund portfolio value is required to reach a minimum size of 10.000.000 TL within one year as of the establishment and the cash collected from fundholders shall be invested within the portfolio restrictions outlined in the Communique (CMB, 2020). Like the REICs, the REIFs are also corporate tax-exempt.

In the light of the development of REIFs, this study, being one of the pioneer studies in this niche and new topic in emerging markets, gives an insight into the Turkish real estate investment funds (T-REIFs) by comparing their risk-return performances with the main benchmark investment tool (BIST-100 Index). This paper also has evaluated the performance of T-REIFs for the four different periods between January 2017 and December 2020 (2017m1-2017m12, 2018m1-2018m12, 2019m1$2019 \mathrm{~m} 12$ and $2020 \mathrm{~m} 1-2020 \mathrm{~m} 12$ ) by applying the Sharpe and Treynor ratios. The analyzed period also includes the Coronavirus Disease (Covid-19) period which is a pandemic declared by the (World Health Organization [WHO], 2020) on March 11, 2020, a few months after it was identified in China and spread all around the world. The pandemic affected the global economy very seriously. International Monetary Fund declared a global recession at the end of March 2020. After a sharp decrease in stocks in the second quarter of 2020 and a deep recession observed in both developed and emerging economies, the economies started gradually recovering in the third quarter of 2020 with the help of the steps taken by governments and central banks (International Monetary Fund [IMF], 2020). Covid-19 also affected the Turkish economy and the real estate industry. Therefore, this study also covered the Covid-19 period in the analysis of the fund performances.

The study compared the rankings of different $\mathrm{T}$ REIFs managed by portfolio management companies and checked if the returns of T-REIFs over or underperform the stock market returns. Based on the results, some recommendations are made to increase both the local and international investments' size in the Turkish real estate capital market.

\section{Literature review}

There are extensive researches about real estate investment funds in the world that cover different aspects of the industry. While some of these studies focused directly on the returns of the funds, others investigated the indirect impacts of different variables such as management characteristics. The study of Philpot and Peterson (2006) investigated the real estate mutual fund performance in the US from risk-adjusted returns and fee perspectives by focusing on the individual management characteristics, and their results exhibited that solo-managed funds have higher risk-adjusted returns compared to team-managed funds. They also underlined the higher risk level approach of the managers with longer tenure. According to their analysis, no correlation was found between the manager characteristics and management fees, but they exhibited that lesser-compensated managers underperform the higher-compensated managers. Fuerst and Matysiak 
(2013) analyzed the performance of non-listed real estate funds by using a panel data analysis, and they exhibited that the distribution yield, direct property returns, fund size, investment style, the performance of the overall economy of the country and asset classes are important parameters for fund performance. Bond and Mitchell (2010) investigated the persistence of the risk-adjusted returns delivered by the fund managers invest in the direct real estate market. According to the results of the analysis they made by covering 280 funds in the UK, only very few managers seemed to make excess risk-adjusted returns and a weak clue of performance persistence in the fund and risk-adjusted fund returns were obtained. Alcock et al. (2013) searched the performance of private equity real estate funds from financial leverage perspective and figured out a correlation between the fund performance and the return on the underlying real estate market. They also concluded that leverage cannot be considered as a long-term strategy to improve performance. Besides these, Sharpe and Treynor performance measures are used for analyzing real estate portfolios. Ong et al. (2012) examined the investment performance of conventional and Islamic Real Estate Investment Trusts listed in Malaysia by using Sharpe and Treynor measures from 20062009 , and they found evidence of underperformance of Shariah REITs compared to conventional REITs. Katzler (2016) used correlation matrices, efficient frontiers, Sharpe ratios, coefficients in equations explaining total returns and $r$-square values in equations for comparing the effectiveness of different property portfolio diversification strategies on the Swedish real estate market. According to her, all methods show that, if any, diversification over types of property is a better strategy on the Swedish market than diversification across regions. Almudhaf and Hansz (2018) calculated the Sharpe ratio statistics for buy-and-hold and trading strategy portfolios of REIT subsectors for the sample period from January 1994 to July 2015 and found that some trading strategies' Sharpe ratios were larger than that of the buy and hold strategy. Almudhaf et al. (2020) investigated the degree of return predictability of lodging/resort REITs for the period January 1994 to May 2016. They discovered that the Sharpe ratios of the trading strategies outperform a simple buy-and-hold strategy.

The researches about the real estate investment funds in Turkey is very limited. In one of the earliest studies made by Sumer (2017), a new investment ecosystem was suggested by combining the real estate investment and pension funds. Sumer and Ozorhon (2019) in their research they made recommended directing the savings in the pension funds to real estate investment funds to finance large investment projects. Benli (2017) also recommended that pension funds may invest in real estate investment funds. None of these researches investigated the real return data of the REIFs because there was no adequate recorded return data to analyze. Due to this limitation, the academic researchers in the past focused more on direct real estate or real estate investment trusts.
Kıyılar and Hepşen (2010) analyzed the risk-adjusted return performances of REITs by comparing them with the average performance of common stocks covering 8 REITs between 2000 and 2008. They used Sharpe and Jensen performance measures and concluded that except two of eight REITs perform better than the overall market portfolio during the sample period. Another research related to BIST-100 Index and risk-adjusted measures made by Bayraktar (2018). The results showed that Treynor and Sharpe ratios rank the REITs consistently for the high-growth periods. Mandaci et al. (2014) studied the long-term relationships between the REIT indices of the Euro-Med zone, including the UK, Israel and Turkey, by using weekly data of 6 years starting from 2003Q3 to 2009Q3, which included the US mortgage crisis and its impacts on global stock markets. Their results exhibited a long-term interaction between the REIT indices of the UK and Israel with that of the US, but no co-movement between REIT indices of Turkey and the US is observed; authors also found that there was a perfect relationship between the UK and the US indices. Icellioglu (2012) made an econometric analysis of the Istanbul housing market. She studied the relation between the housing price index and the rent index of the chosen districts of the city. The results of her analysis exhibited that an increase of 1-unit price for the house prices causes an increase of 0.68 -unit price for the rents.

Yildirim (2012) defined the risks in the real estate industry and analyzed the risk-return calculations. The results showed that any volatility in the real estate sector affected the financial markets. The problems behind not being able to calculate the risks are determined as the insufficiency of valuation standards, the volatility of capital structures and political instability. Sumer and Ozorhon (2020) studied the impact of foreign currency (USD/TL) on the returns of REIC and home price indices, and their findings revealed that although the returns of the REIC index are influenced by currency fluctuations, there is no statistical meaning for the returns of the home price index. In that context, this study seems to be one of the first researches investigating the returns of the REIFs in Turkey.

\section{Real estate investment funds}

A real estate fund mainly invests in investment tools offered by real estate companies. Although the main investment areas of real estate funds are commercial assets; raw land, residential buildings and agricultural spaces may also be included in their investments, as well as the Real Estate Investment Trusts. According to the Preqin Real Estate Report (2020), the total asset under management (AuM) of global real estate investment funds is 909 billion USD at the end of $1 \mathrm{H} \mathrm{2018}$. The same report indicates that $38 \%$ of the institutional investors that invest in real estate are private and public pension funds. Figure 1 shows the institutional types of international real estate investors. 


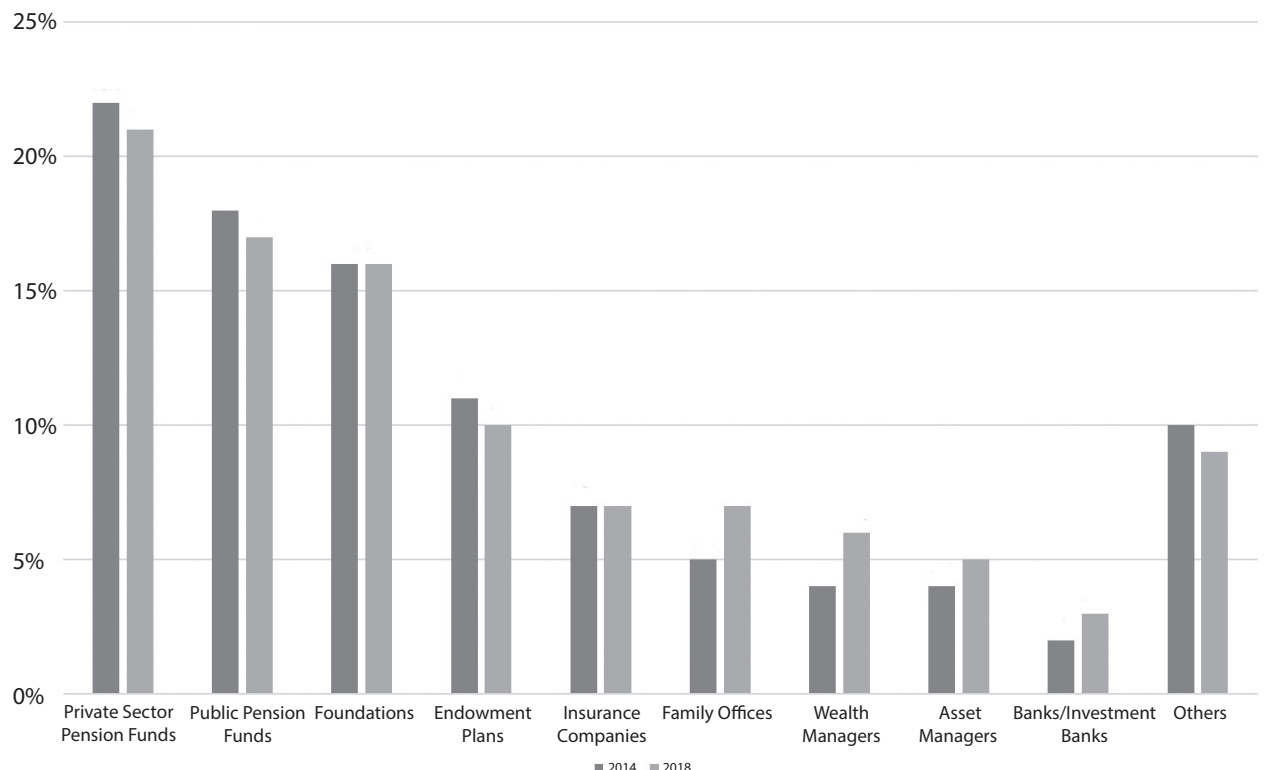

Figure 1. Institutional investors in real estate by type 2014 vs. 2018 (Preqin, 2020)

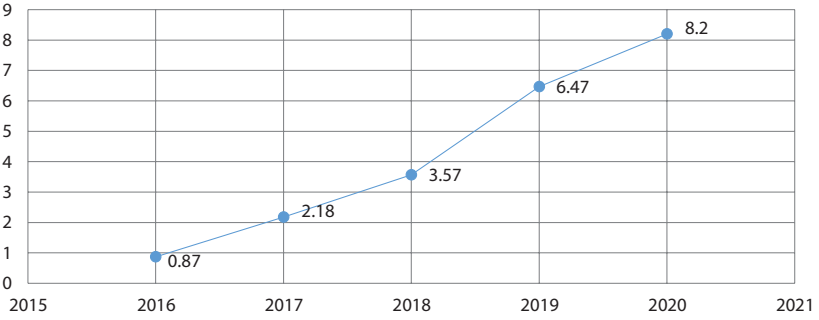

Figure 2. Net asset value of T-REIFs 2016-2020 (Capital Markets Board of Turkey, 2020)

The PwC Real Estate Report (2020) emphasizes the importance of emerging economies, and these economies are expected to be the focal points of global real estate investors. In that context, the Turkish real estate market carries a huge potential for international investors. As of the end of third quarter of 2020, the total size of the real estate investment companies (REICs) is 5,51 billion USD. Although the regulations about real estate investment funds (REIFs) were issued almost 20 years later than the REICs, the net asset value, by more than doubling the value in 2020 , reached to 8,2 billion TL, around 1,1 billion USD (Capital Markets Board of Turkey, 2020). Figure 2 shows the net asset values of the REIFs.

According to the report of the (Public Disclosure Platform [KAP], 2020), the T-REIFs mostly invest in mixeduse projects. This is followed by office and housing investments. Figure 3 shows the investment area distribution of the T-REIFs.

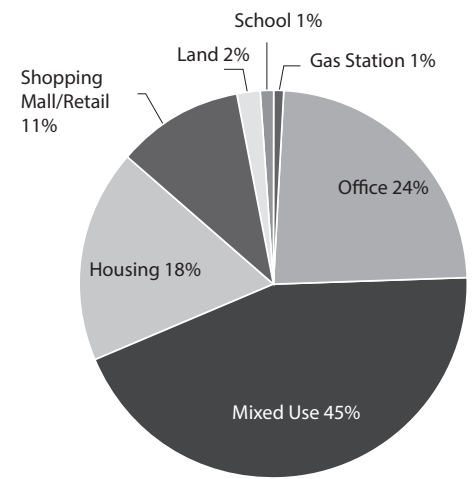

Figure 3. Investment area distribution of the REIFs in Turkey (KAP, 2020)

\section{Methodology}

The main goal of an investor is to increase the worth of the investment he/she obtains. To do that, investors are seeking to create the highest potential return on their investment. Investors typically find the quality of the separate investments based on previous results. According to Wang and Webb (2009), the rankings based on the past return data may be biased due to the target risk level of the portfolio and the market performance. It is therefore essential to investigate the performance of the portfolio independently of the risk sensitivity and market strength, provided that such a risk-adjusted performance measure adjusts the return of the portfolio by the number due to the relative risk of the portfolio, given the market strength of the amount under investigation. Using such a measure, portfolios with abnormally high or low-risk levels will not be likely to earn abnormally high or low return marks, regardless of market performance (Haugen, 1997). 
Portfolio returns are compared with each other and with the market in general by using common well-known methods. An easy way is comparing their returns, however; returns are not the only selection criteria for investors. The portfolio which has a lower risk is preferred compared with a portfolio with higher risk but the same return. There are 3 common ratios that measure the risk-adjusted performance of the portfolio in investment decisions: Sharpe's ratio (Sharpe, 1966), Treynor's ratio (Treynor, 1965), and Jensen's Alpha (Jensen, 1968) that are based on the principles of Capital Asset Pricing Model (CAPM) $)^{1}$ (Lintner, 1965; Sharpe, 1964). While the first two ratios are based on the ratio of return to risk, the third is a measure of relative performance based on the Security Market Line (SML).

As mentioned, the measurement of the performance of funds was an important part of the financial literature of developing countries in the early 1960s. The standard performance measures known as the Sharpe ratio, Treynor ratio, and Jensen's alpha were introduced independently by Sharpe (1966), Treynor (1965) and Jensen (1968).

Sharpe (1966) developed the Sharpe ratio, as the ratio of a portfolio's total return minus the risk-free rate divided by the standard deviation of the portfolio, which is a measure of its risk. The Sharpe ratio is essentially the risk premium per unit of risk, which is determined by the standard deviation of the portfolio. Sharpe efficiency is a generally accepted indicator for evaluating the risk-adjusted returns of different investment groups. The Sharpe ratio is mathematically described as:

$$
S_{p}=\frac{\left(R_{p}-R_{f}\right)}{\sigma_{p}},
$$

where: $S_{p}$ is the Sharpe ratio of performance; $R_{p}$ is the return of the portfolio; $R_{f}$ is the risk-free rate of return; $\sigma_{p}$ is the standard deviation of the portfolio. If the Sharpe ratio is higher among various portfolios the performance is expected to be better because the Sharpe ratio measures the performance of the portfolio compared to the risk taken by taking into consideration the benefits and costs of investing and reflects the risk levels of investment decisions. Not requiring the benchmark as a market proxy seems to be the advantage of Sharpe ratio, but the ratio works at non-diversified or poorly diversified portfolios.

On the other hand, the Treynor ratio uses beta or systematic risk in the denominator and is described as:

$$
T_{p}=\frac{\left(R_{p}-R_{f}\right)}{\beta_{p}},
$$

where: $T_{p}$ is the Treynor ratio of performance; $R_{p}$ is the return of the portfolio; $R_{f}$ is the risk-free rate of return; $\beta_{p}$ is the beta of the portfolio. Treynor aimed to indicate a performance measure that could be applied to all inves-

\footnotetext{
${ }^{1}$ In CAPM, estimated rate of return is determined by incorporating the systematic risk which is measured by beta and risk-free rate and then multiplied by the market risk premium of the expected market return minus the risk-free rate.
}

tors regardless of their personal risk preferences. In fact, according to Treynor, there were two risk components: the risks arising from fluctuations in the stock market and individual securities. Treynor also presented the concept of a security market line that defines the relationship between portfolio returns and the market rate of returns by measuring the relative volatility (as represented by beta) between the portfolio and the market. The beta coefficient is the measure of the market volatility of the portfolio itself. The higher the line slope, the greater the risk-return trade-off (Treynor, 1965).

There is no guarantee of a positive excess return or beta for a portfolio; when excess return or beta is negative, in that case, problems arise for the standard Sharpe and Treynor ratio interpretation. Along with the results, if some negative Sharpe ratio and Treynor ratio values are observed, these negative ratios can lead to anomalies for making the ranking. Israelsen (2009) has created a modified Sharpe ratio successfully and this resolves the counterintuitive results produced by the Sharpe ratio when $\left(R_{p}-R_{f}\right)$ is negative:

$$
S_{p}=\frac{\left(R_{p}-R_{f}\right)}{\sigma_{p} \frac{E R}{a b s E R}} .
$$

In similar logic, to resolve the counterintuitive results, Treynor ratios are also modified in the same way (Bayraktar, 2018):

$$
T_{p}=\frac{\left(R_{p}-R_{f}\right)}{\beta_{p}^{\frac{E R}{a b s E R}}} .
$$

\section{Data and results}

The purpose of this paper is to give an insight into the real estate investment funds (REIF) in Turkey by comparing their risk-return performances with the main benchmark investment tool (BIST-100 Index). This paper also has evaluated the performance of REIFs in Turkey for the four different periods between January 2017 and December 2020 (2017m1-2017m12, 2018m1-2018m12, 2019m1$2019 \mathrm{~m} 12$ and $2020 \mathrm{~m} 1-2020 \mathrm{~m} 12$ ) by applying the Sharpe ratio and Treynor ratio. The average annual rate of return on treasury bills of the Central Bank of Turkey (CBT) has been used as the risk-free rate of return, whereas the research uses the Borsa Istanbul Stock Exchange Index, BIST-100, as the benchmark. All returns of T-REIFs have been taken from a real estate portfolio company (that is a portfolio management company licensed by Capital Markets Board of Turkey and the main activity is to establish and manage real estate and venture capital investment funds) while BIST-100 index data have been obtained from the website of the Borsa Istanbul Stock Exchange (2020) for the analyzed period.

In our study, six different types of REIFs are analyzed; REIF-1, launched in 2017, invests in strategic lands and landed properties in Turkey. Similar to REIF-1, REIF-2 
(launched in 2018) aims to invest in strategic lands and landed properties in Turkey after raising capital in the medium and long terms. The investment strategy of the REIF-3, launched in 2018, is to acquire a shopping center located in Istanbul for value increase, purchase profit and rental income. On the other hand, the investment strategy of the REIF-4, launched in 2019, is to provide regular and increasing returns to investors through the rental income to be obtained by investing in commercial real estate, mainly office spaces. REIF-5, launched in 2020, invests in various properties, especially housing, which is below the appreciated value and reconstruction value in the independent valuation reports it has made. The goal of the fund (REIF-5) is to gain value gain by exiting the new housing price level that will occur when new projects are developed as a result of supply contraction with increasing construction costs with inflation and to increase the income by renting out houses in this process. Finally, REIF-6, launched in 2020, aims to gain in value increase and rental income by investing in commercial real estate, land, residence, office, shopping center, hotel, logistics center, warehouse, parking lot, dormitory, hospital and all kinds of real estate approved by the Capital Markets Board of Turkey.
The analyzed four-year period from 2017 to 2020 is characterized by a volatile impact of the local and international economic turmoil, which also affected the Turkish real estate industry. In 2018, the Turkish real estate sector was in crisis due to volatility in interest rates, currency exchanges, inflation caused by political tensions and increased land and construction costs in the last decade and the decrease in the sales transactions directly affects the fund performances. On the other hand, there were very considerable results in 2020, especially in the Covid-19 period. Although a negative effect on returns was expected in the Covid-19 period, the results obtained were the opposite, thanks to the decreased mortgage loan rates provided by the public banks which rapidly increased the sales transactions and sales prices in the second and third quarter of 2020, The sharp devaluation of the Turkish Lira in the third quarter of 2020 may also be considered another important point that may have effects in the increase in the returns due to the historically cheapest prices of the real estate in foreign currencies.

Table 1 and Figures 4-10 show the statistical summary and monthly returns for benchmark index (BIST100) and all covered REIFs for the period between 2017 and 2020 .

Table 1. Summary of basic performance statistics during January 2017-October 2020

\begin{tabular}{|l|c|c|c|c|c|c|c|}
\hline & BIST-100 & REIF-1 & REIF-2 & REIF-3 & REIF-4 & REIF-5 & REIF-6 \\
\hline Mean & 0.0154 & 0.0102 & 0.0109 & 0.0106 & 0.0085 & 0.0156 & 0.0170 \\
\hline Median & 0.0202 & 0.0040 & 0.0037 & 0.0037 & 0.0059 & 0.0045 & 0.0161 \\
\hline Max. & 0.1539 & 0.0928 & 0.0801 & 0.1353 & 0.0619 & 0.0422 & 0.1057 \\
\hline Min. & -0.1543 & -0.0120 & -0.0086 & -0.0903 & -0.0261 & 0.0008 & -0.0222 \\
\hline Std. Dev. & 0.0725 & 0.0175 & 0.0181 & 0.0364 & 0.0163 & 0.0160 & 0.0304 \\
\hline Skewness & -0.1694 & 2.6567 & 2.5387 & 1.2418 & 1.2437 & 0.6319 & 2.0382 \\
\hline Kurtosis & -0.6806 & 9.6040 & 6.9109 & 5.0846 & 4.2317 & -1.5797 & 6.1331 \\
\hline Observation & 48 & 48 & 36 & 36 & 24 & 12 & 12 \\
\hline
\end{tabular}

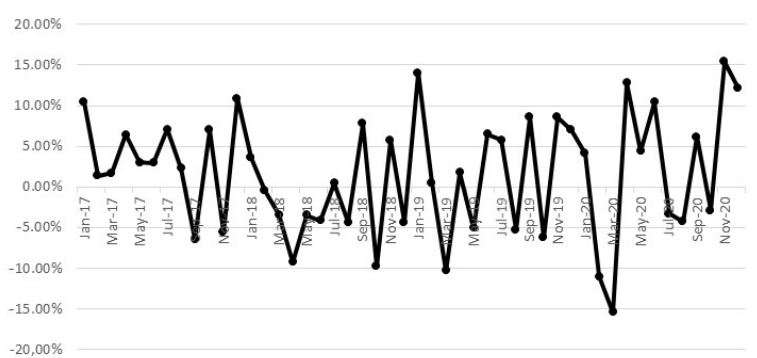

Figure 4. BIST-100 monthly return (\%)

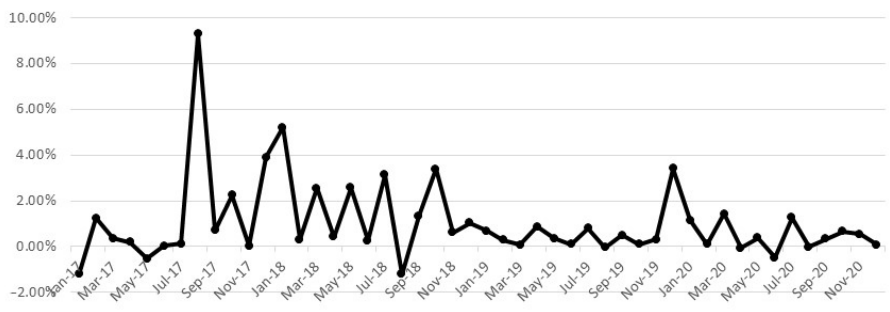

Figure 5. REIF-1 monthly return (\%) 


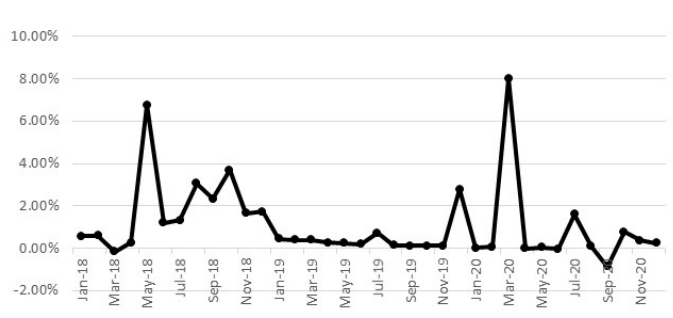

Figure 6. REIF-2 monthly return (\%)

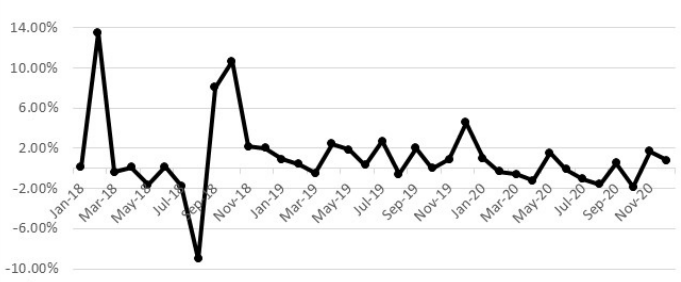

Figure 7. REIF-3 monthly return (\%)

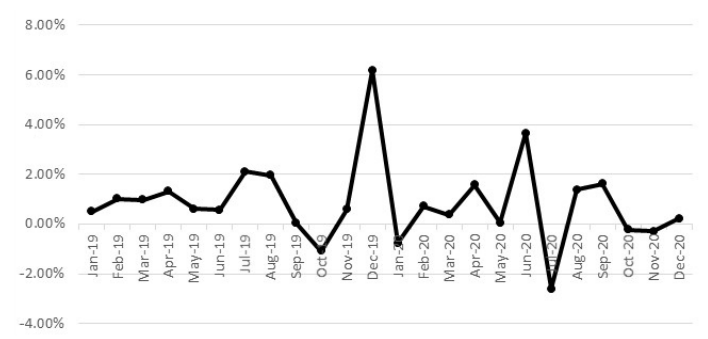

Figure 8. REIF-4 monthly return (\%)

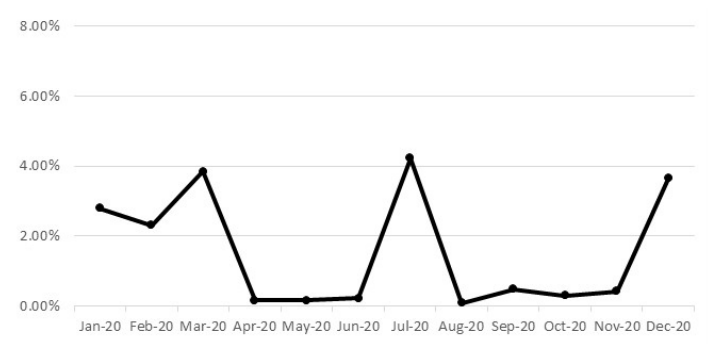

Figure 9. REIF-5 monthly return (\%)

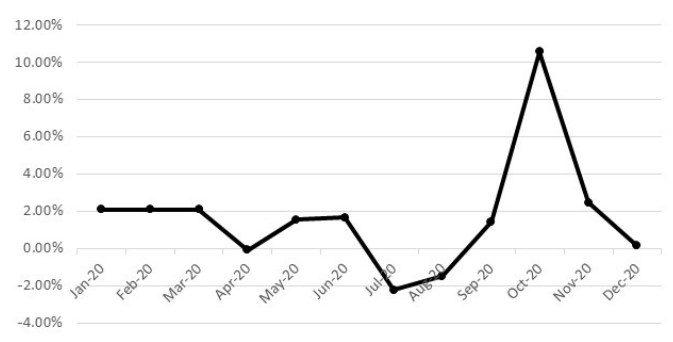

Figure 10. REIF-6 monthly return (\%)
Table 2 summarizes the performance comparison of REIFs with BIST-100 for different sub-periods. As a basic comparison, the coefficient of variation is helpful when using the risk/return ratio to select investments. In finance, the coefficient of variation allows investors to determine how much volatility, or risk, is assumed in comparison to the amount of return expected from investments. Ideally, the lower the ratio of the standard deviation to mean return, the better the risk-return trade-off. In that case, except for the year-2017, REIFs' risk/return performance is better than that of the stock market index over the analyzed period. However, since excess returns (returns relative to a risk-free rate) and systematic risks are not taken into consideration, focusing only average risk/return ratio of funds and benchmark index does not provide a deep insight into the justification of the active management of funds, which is the task of the research. Therefore, comparing the risk-excess returns of the REIFs and BIST-100 index is essential. From this point of view, Sharpe and Treynor rates are calculated annually due to the different traded periods of REIFs. However, there are some negative Sharpe ratio and Treynor ratio values, these values are modified as Israelsen (2009) and Bayraktar (2018) did in their studies for correcting the rankings.

As a general rule, if the Sharpe ratio $(\mathrm{Si})$ is between 1.0 and 1.99, the fund has an acceptable performance; if the ratio is between 2.00 and 2.99, the fund has a great performance; on the other hand, outstanding funds have a Sharpe ratio more than 3.0 (Jagric et al., 2007). As mentioned, the higher the Sharpe ratio, the better the fund performance and negative ratios are modified for correcting the rankings. For the first period $(2017 \mathrm{ml}-$ $2017 \mathrm{~m} 12)$, there was only one real estate investment fund (REIF-1) traded and its Sharpe ratio was lower than the benchmark index (BIST-100). However, it is seen that there is no significant difference in the Sharpe (whether modified or not) ratios of REIF-1 and BIST-100 performances. During January 2018-December 2018 period, the highest modified Sharpe ratio was observed in the case of fund REIF-3 (mod.Si $=+0.23$ ), which makes the fund with the positive excess return per unit of total risk, whereas the fund REIF-1 obtained the lowest Sharpe ratio $(\bmod . S i=+0.07)$. Therefore, according to the modified Sharpe ratio, analyzed funds have superior performance compared to the benchmark (BIST-100) in the year 2018. In the year 2019, the Sharpe ratio of all REIFs are lower than the BIST-100's ratio due to negative excess return; however, in the last analyzed period (the year-2020), the money expansion of the Turkish government and the decreased mortgage loan rates in the second quarter of 2020 had positive effects on the housing market. That situation enhanced the fund performances of the REIFs analyzes in the Covid-19 period, especially REIF-5 $(\bmod . S i=+0.35)$ and REIF-6 $(\bmod . S i=+0.23)$, which invest in the housing market, have superior performances relative to BIST-100 and the other REIFs. 
Table 2. Comparison of REIFs' and BIST 100's performances for different sub-periods

\begin{tabular}{|c|c|c|c|c|c|c|c|}
\hline & BIST-100 & REIF-1 & REIF-2 & REIF-3 & REIF-4 & REIF-5 & REIF-6 \\
\hline \multicolumn{8}{|c|}{ Period 1: The year 2017} \\
\hline Sharpe ratio ${ }^{2}$ & 0.45 & 0.14 & & & & & \\
\hline Modified Sharpe & 0.45 & 0.14 & & & & & \\
\hline Ranking & 1 & 2 & & & & & \\
\hline Treynor ratio & 0.02 & 0.14 & & & & & \\
\hline Modified Treynor & 0.02 & 0.14 & & & & & \\
\hline Ranking & 2 & 1 & & & & & \\
\hline$\beta$ coefficient & 1.00 & 0.03 & & & & & \\
\hline Coefficient of variation & 1.59 & 2.07 & & & & & \\
\hline \multicolumn{8}{|c|}{ Period 2: The year 2018} \\
\hline Sharpe ratio & -0.61 & 0.07 & 0.23 & 0.08 & & & \\
\hline Modified Sharpe & -0.18 & 0.07 & 0.23 & 0.08 & & & \\
\hline Ranking & 4 & 3 & 1 & 2 & & & \\
\hline Treynor ratio & -0.03 & 0.03 & -0.08 & 0.04 & & & \\
\hline Modified Treynor & -0.03 & 0.03 & -0.08 & 0.04 & & & \\
\hline Ranking & 3 & 2 & 4 & 1 & & & \\
\hline$\beta$ coefficient & 1.00 & 0.04 & -0.05 & 0.13 & & & \\
\hline Coefficient of variation & * & 1.08 & 0.99 & 3.03 & & & \\
\hline \multicolumn{8}{|c|}{ Period 3: The year 2019} \\
\hline Sharpe ratio & 0.10 & -0.71 & -0.99 & -0.09 & -0.09 & & \\
\hline Modified Sharpe & 0.10 & -0.85 & -0.84 & -0.23 & -0.32 & & \\
\hline Ranking & 1 & 5 & 4 & 2 & 3 & & \\
\hline Treynor ratio & 0.01 & -0.17 & -0.39 & -0.02 & -0.04 & & \\
\hline Modified Treynor & 0.01 & -3.57 & -2.12 & -1.35 & -0.74 & & \\
\hline Ranking & 1 & 5 & 4 & 3 & 2 & & \\
\hline$\beta$ coefficient & 1.00 & 0.05 & 0.02 & 0.09 & 0.04 & & \\
\hline Coefficient of variation & 3.47 & 1.48 & 1.52 & 1.20 & 1.45 & & \\
\hline \multicolumn{8}{|c|}{ Period 4: The year 2020} \\
\hline Sharpe ratio & 0.14 & -0.87 & -0.05 & -0.86 & -0.32 & 0.35 & 0.23 \\
\hline Modified Sharpe & 0.14 & -0.32 & -0.27 & -1.31 & -0.78 & 0.35 & 0.23 \\
\hline Ranking & 3 & 5 & 4 & 7 & 6 & 1 & 2 \\
\hline Treynor ratio & 0.01 & 0.18 & 0.01 & -0.18 & -0.13 & -0.08 & -0.19 \\
\hline Modified Treynor & 0.01 & 1.51 & 1.66 & -6.38 & -1.86 & -0.08 & -0.19 \\
\hline Ranking & 3 & 2 & 1 & 7 & 6 & 4 & 5 \\
\hline$\beta$ coefficient & 1.00 & -0.03 & -0.14 & 0.06 & 0.04 & -0.07 & -0.04 \\
\hline Coefficient of variation & 4.13 & 1.31 & 2.70 & * & 3.22 & 1.07 & 1.87 \\
\hline
\end{tabular}

Note: ${ }^{*}$ When the expected return in the denominator is negative, the coefficient of variation could be negative according to the definition. In that case, the result of the $\mathrm{CV}$ is meaningless.

As Bayraktar (2018) mentioned in her study, the performance rankings by Sharpe ratio theoretically can differ from Treynor ratio (Ti) since Sharpe ratio depends on the volatility of return, while Treynor ratio depends on systematic risk (beta) as the relevant risk factor. In the year 2017, there was only one REIF traded on the market and

\footnotetext{
${ }^{2}$ The Sharpe ratio compares the average monthly excess return of a REIF against the monthly return of the two-year TR treasury bond.
}

its Treynor ratio $(T i=+0.14)$ was higher than the BIST$100(T i=+0.02)$. According to the Treynor ratio calculated in the year 2018, beta coefficients were positive for REIF-1 and REIF-3, whereas REIF-2 had a negative beta. In that year, modified Treynor ratios of REIF-1 (mod.Ti $=+0.03$ ) and REIF-3 (mod.Ti $=+0.04)$ had superior performances rather than BIST-100 (mod.Ti $=-0.03)$, whereas REIF-2 $(\bmod . T i=-0.08)$ had the lowest ratio. However, the funds REIF-1, REIF-2, REIF-3, and REIF-4 had a positive beta coefficient in the third period (2019m1-2019m12), excess 
returns were negative. This made the Treynor ratios of all REIFs were lower than the benchmark index. The calculated Treynor ratios for REIF-1 and REIF-2 had greater systematic risk-return performances than both BIST-100 and the rest of funds in the year 2020. Modified Treynor ratios of REIF- 1 and REIF- 2 were +1.51 and +1.66 respectively.

As Bayraktar (2018) found similar results in her study for REITs in Turkey; we observed some real contrasts in ranking orders of Sharpe and Treynor in the year-2018 and the last period for REIFs. For instance, in the year 2018, the REIF-2 was ranked first by Sharpe ratio, but it was only the fourth in the ranking by Treynor; similarly, in the year 2020, the REIF-5 ranked as first according to Sharpe but ranked as fourth by Treynor ratio. In a welldiversified portfolio both ratios give the same results but in the presence of non-systematic risk and the portfolio is poorly diversified, the Treynor ratio is a better indicator than the Sharpe ratio. The results that exhibited different ranking of funds by Sharpe and Treynor ratios also supports the fact that the portfolios of funds in the Turkish real estate market are not well diversified. According to the Communique issued by CMB of Turkey dated in 2017, $10 \%$ of the savings accumulated in the pension funds must be directed to real estate investment funds and venture capital investment funds. Since then the size of the real estate investment funds started increasing and reached 8,22 billion TL in a short period. Moreover, the sharp devaluation of the Turkish Lira against the United States Dollar in the last two years decreased the asset prices in foreign currencies. The government also issued a new act in 2018 that enabled the foreign country citizens to become Turkish citizens in the case they invest in the Turkish real estate funds at least 500.000 USD. Considering the new acts and regulations and historically low real estate asset values due to the devaluation of the Turkish Lira, the current situation of the Turkish real estate market provides a big opportunity to foreign investors if the real estate investment funds diversify their fund portfolios.

\section{Conclusions}

Turkey is one of the largest economies in Europe and with its young, dynamic and increasing population, its strategic location being a bridge between Europe and Asia, it is a candidate for being one of the most attractive destinations for both local and international investors. The real estate industry in Turkey has been developing for the last few decades. The investors seek long-term income where they can generate monthly income as well as a benefit from the value increase of the assets when they exit. The recent decrease in the value of the Turkish Lira (TL) against Euro and USD brings a big opportunity to foreign investors while considering investing in the Turkish real estate market, especially from the values of the assets' perspectives. Direct investment in real estate may be time-consuming and/or costly. As a result, investors seeking to enhance their portfolio performance with real estate usually prefer to invest indirectly in real estate. This can be achieved by investing in real estate investment funds. The real estate investment fund industry in Turkey has experienced rapid growth since 2016. The number of real estate investment funds grew from 2 in 2016 to 50 in the year 2020, and the total market capitalization increased from 870 million TL to 8,22 billion TL. This upward trend indicates that T-REIFs are becoming more important in the Turkish real estate market. From this point of view, the aim of this paper is to give an insight into the real estate investment funds by comparing their risk-return performances with the main benchmark investment tool, BIST-100 Index. There are two important point that we emphasize in this study; the first one is due to different establishment dates of the REIFs, we evaluated and ranked the risk-return performances of REIFs and BIST-100 index for the four different period between January 2017 and December 2020 (2017m1-2017m12, 2018m1-2018m12, 2019m1$2019 \mathrm{~m} 12$ and $2020 \mathrm{~m} 1-2020 \mathrm{~m} 12$ ) by applying the Sharpe ratio and Treynor ratio; and the second point is that, since some negative Sharpe ratio and Treynor ratio values were obtained as a result of the analysis, these values were modified similar to how Israelsen (2009) and Bayraktar (2018) did in their studies for correcting the rankings. Monthly REIF returns were obtained from a real estate portfolio management company, returns of the benchmark investment tool-BIST 100 were taken from Borsa Istanbul Stock Exchange (2020) and the monthly return of the two-year Turkish treasury bond was selected as a risk-free rate.

In the first period $(2017 \mathrm{~m} 1-2017 \mathrm{~m} 12)$, there was only one real estate investment fund (REIF-1) traded and however its Sharpe ratio was lower than the benchmark index, BIST-100; on the other hand, its Treynor ratio was higher than the BIST-100. For the second period, according to the modified Sharpe ratio, analyzed funds had superior performance compared to BIST-100, but REIF-1 and REIF-3 had superior performances rather than BIST-100 according to Treynor ranking. In the year 2019, not only the Sharpe ratio of all REIFs were lower than the BIST100's ratio; but also it was the same for Treynor ranking due to negative excess return. In that year, BIST-100 had superior risk-return performances rather than REIFs. In the year 2020, the money expansion of the Turkish government and the decreased mortgage loan rates in the second quarter of 2020 had positive effects on the housing market. That situation enhanced the fund performances of the REIFs analyzes in the Covid-19 period, especially REIF-5 and REIF-6, which invest in the housing market, had superior performances relative to BIST-100 and the other REIFs. The calculated Treynor ratios for REIF-1 and REIF-2 had greater systematic risk-return performances than both BIST-100 and the rest of the funds in the last analyzed period. As explained, in a well-diversified portfolio both ratios give the same results but in the presence of non-systematic risk and the portfolio is poorly diversified, the Treynor ratio is a better indicator than the Sharpe ratio. The results that exhibited different ranking of funds 
by Sharpe and Treynor ratios also supports the fact that the portfolios of funds in the Turkish real estate market are not well diversified.

According to the Communique issued by CMB of Turkey dated in 2017, 10\% of the savings accumulated in the pension funds must be directed to real estate investment funds and venture capital investment funds. Since then the size of the real estate investment funds started increasing and reached 8,22 billion TL in a short period. Moreover, the sharp devaluation of the Turkish Lira against the United States Dollar in the last two years decreased the asset prices in foreign currencies. The government also issued a new act in 2018 that enabled the foreign country citizens to become Turkish citizens in the case they invest in the Turkish real estate funds at least 500.000 USD. Considering the new acts and regulations and historically low real estate asset values due to the devaluation of the Turkish Lira, the current situation of the Turkish real estate market provides a big opportunity to foreign investors if the real estate investment funds diversify their fund portfolios.

The Turkish real estate market is considered a developing market. In order to shift from the developing market to the investment market, where many institutional foreign investors focus on, it is essential to establish more real estate investment funds and attract investors. The regulation that CMB issued in 2014 to establish REIFs was the first important step, and that was followed by enabling the pension funds to invest in the REIFs. Compared with the total size of the global REIF market, there is still a long way to go for the Turkish real estate market.

The conducted article has two important limitations. The first is related to the time constraint. Since the history of the REIFs in Turkey goes back only to 2014, the data used in this study was limited. Therefore, the reliability of the results exhibited in this study shall take into consideration that limitation. This research targeted to make preliminary research in the area where no past studies conducted yet and aimed at presenting methodological aspects of future work with a larger database. It is also important to note that this study covered the Covid-19 effects on the returns of the analyzed funds and BIST 100 index. It is recommended to consider the further effects of the second wave of the pandemic. The second limitation is related to the economic volatility experienced during the data analysis period. The analyzed four-year period from 2017 to 2020, especially in 2018, is characterized by a negative effect of the local economic turmoil, which also affected the Turkish real estate market. In this period, the Turkish real estate industry was in crisis due to volatility in interest rates, currency exchanges, inflation, increased land and construction costs in the last decade and the decrease in the sales transactions directly affects the fund performances. On the other hand, the money expansion of the Turkish government and the decreased mortgage loan rates in the second quarter of 2020 had positive effects on home sales and increased housing prices. That situation enhanced the fund performances of the REIFs analyzes in the Covid-19 period. A further study is recommended to be conducted with extended data and cover the regular and crisis periods.

Finally, by providing corporate tax exemptions, and by enabling the investors to diversify their investments and reduce their risks, real estate investment funds are important alternatives to direct real estate investments. In that context, analyzing the return performances of REIFs and comparing them with BIST 100 index contribute to the literature and provide insight to investors who may consider investing in Turkish real estate capital market instruments. As far as investigated in the literature, this study considers being one of the pioneer researches that focuses on the return performances of REIFs in Turkey.

\section{Acknowledgments}

Authors are thankful to Mr. Craig Israelsen for his kind support and contribution to this paper.

\section{Author contributions}

Mehmet Emre Çamlıbel was the corresponding author and responsible for the research design and the data collection. Levent Sümer was responsible for the methodology and model development. Ali Hepşen developed the data analysis and the conclusion.

\section{Disclosure statement}

The authors declare that they have no competing financial, professional, or personal interests from other parties.

\section{References}

Aggarwal, R., Klapper, L., \& Wysocki P. D. (2003). Portfolio preferences of foreign institutional investors (World Bank Policy Research Working Paper No. 3101). http://documents1. worldbank.org/curated/en/984761468764046884/103503322 _20041117165009/additional/wps3101.pdf

Alcock, J., Baum, A., Colley, N., \& Steiner, E. (2013). The role of financial leverage in the performance of private equity real estate funds. The Journal of Private Equity, 17(1), 80-91. https://doi.org/10.2139/ssrn.2213190

Almudhaf, F., \& Hansz, A. J. (2018). Random walks and market efficiency: evidence from real estate investment trusts (REIT) subsectors. International Journal of Strategic Property Management, 22(2), 81-92. https://doi.org/10.3846/ijspm.2018.440

Almudhaf, F., Aroul, R. R., \& Hansz, J. A. (2020). Are markets adaptive? Evidence of predictability and market efficiency of lodging/resort REITs. International Journal of Strategic Property Management, 24(2), 130-139.

https://doi.org/10.3846/ijspm.2020.11547

Bayraktar, S. (2018). Performance stability of Turkish REITs. In S. Gokten, \& G. Kucukkocaoglu (Eds.), Financial management from an emerging market perspective (chapter 16, pp. 811-879). IntechOpen.

https://doi.org/10.5772/intechopen.71629

Benli, A. (2017). Türkiye'de gayrimenkul yatırım fonlarının bireysel emeklilik sistemine dahil edilmesi ve bu değişimin sermaye piyasalarma etkisi [Master thesis]. Marmara University, Istanbul, Turkey. 
Bond, S. A., \& Mitchell, P. (2010). Alpha and persistence in real estate fund performance. Journal of Real Estate Finance and Economics, 41, 53-79.

https://doi.org/10.1007/s11146-009-9230-y

Borsa Istanbul Stock Exchange. (2020, December 31). Borsa Istanbul stock exchange data sets. https://www.borsaistanbul.com/

Capital Market Board. (2020, May 31). Communiqué on real estate investment funds. http://www.cmb.gov.tr/SiteApps/Teblig/File/491

Capital Markets Board of Turkey. (2020, December 31). Monthly bulletin. https://www.spk.gov.tr/SiteApps/Yayin/AylikIstatistikBultenleri

Fuerst, F., \& Matysiak, G. (2013). Analysing the performance of nonlisted real estate funds: a panel data analysis. Applied Economics, 45(14), 1777-1788.

https://doi.org/10.1080/00036846.2011.637898

Haugen, R. A. (1997). Modern investment theory (4th ed.). Prentice Hall.

Icellioglu, C. S. (2012). Real estate investments in the economic and financial perspective: econometric analysis of Istanbul housing market (2008-2011) [Ph.D. thesis]. Istanbul University, Istanbul, Turkey.

International Monetary Fund. (2020). COVID-19: how to record government policy interventions in fiscal statistics. https://www. imf.org/en/Publications/SPROLLs/covid19-special-notes

Israelsen, C. (2009). Refining the Sharpe ratio. Journal of Performance Measurement, 13(3), 23-27.

Jagongo, A., \& Mustwenje, V. S. (2014). A survey of the factors influencing investment decisions: the case of individual investors at the NSE. International Journal of Humanities and Social Science, 4(2), 92-102.

Jagric, T., Podobnik, B., Strasek, S., \& Jagric, V. (2007). Riskadjusted performance of mutual funds: some tests. SouthEastern Europe Journal of Economics, 2, 233-244.

Jensen, M. C. (1968). The performance of mutual funds in the period 1945-1964. Journal of Finance, 23(2), 389-416. https://doi.org/10.1111/j.1540-6261.1968.tb00815.x

Katzler, S. (2016). Methods for comparing diversification strategies on the Swedish real estate market. International Journal of Strategic Property Management, 20(1), 17-30. https://doi.org/10.3846/1648715X.2015.1120789

Kiyılar, M., \& Hepşen, A. (2010). Performance appraisal of real estate investment trusts (REITs): a practice in Istanbul Stock Exchange. İstanbul Üniversitesi İşletme Fakültesi İşletme İktisadı Enstitüsü Yönetim Dergisi, 21(65), 11-23. https://dergipark.org.tr/tr/pub/iuiieyd/issue/9199/377025

Lintner, J. (1965). Security prices, risk and maximal gains from diversification. Journal of Finance, 20(4), 587-615. https://doi.org/10.1111/j.1540-6261.1965.tb02930.x
Mandaci, P. E., Aktan, B., \& Cagli, E. C. (2014). Co-movements of REIT indices with structural changes before and during the subprime mortgage crisis: evidence from Euro-Med markets. International Journal of Strategic Property Management, 18(1), 1-10. https://doi.org/10.3846/1648715X.2013.849302

Ong, T. S., Teh, B. H., Soh, C. H., \& Yan, Y. L. (2012). Malaysian real estate investment trusts: a performance and comparative analysis. International Journal of Economics and Finance, 4(5), 73-84. https://doi.org/10.5539/ijef.v4n5p73

Philpot, J., \& Peterson, C. A. (2006). Manager characteristics and real estate mutual fund returns, risk and fees. Managerial Finance, 32(12), 988-996. https://doi.org/10.1108/03074350610710481

Preqin. (2020, May 31). Global real estate report. https://docs.preqin.com/samples/2020-Preqin-Global-Real-Estate-ReportSample-Pages.pdf

Public Disclosure Platform. (2020, May 31). Real estate investment funds. https://www.kap.org.tr/en/YatirimFonlari/GMF

PwC. (2020, May 31). Real estate 2020: building the future. https://www.pwc.com/sg/en/real-estate/assets/pwc-real-estate2020-building-the-future.pdf

Sharpe, W. F. (1964). Capital asset prices: a theory of market equilibrium under conditions of risk. Journal of Finance, 19(3), 425-442. https://doi.org/10.1111/j.1540-6261.1964.tb02865.x

Sharpe, W. F. (1966). Mutual fund performance. Journal of Business, 39(6), 119-138. https://doi.org/10.1086/294846

Sumer, L. (2017). Developing a real estate-pension fund investment ecosystem: Turkey real estate fund [Ph.D. thesis]. Bogazici University, Istanbul, Turkey.

Sumer, L., \& Ozorhon, B. (2019). The shortcomings of pension system in Turkey: solutions with a new model proposed. International Journal of Islamic Economics and Finance Studies, 5(2), 23-48. https://doi.org/10.25272/ijisef.559898

Sumer, L., \& Ozorhon, B. (2020). The exchange rate effect on housing price index and REIT index return rates. Finansal Araştırmalar ve Çalışmalar Dergisi, 12(22), 249-266. https://doi.org/10.14784/marufacd.688468

Treynor, J. L. (1965). How to rate management investment funds. Harvard Business Review, 44(1), 63-75.

World Health Organization. (2020). WHO announces COVID-19 outbreak a pandemic. www.euro.who.int/en/healthtopics/health-emergencies/coronavirus-covid-19/news/ news/2020/3/who-announces-covid-19-outbreak-a-pandemic

Yildirim, H. H. (2012). Calculation of risk-return on real estate investments [Master thesis]. Marmara University, Istanbul, Turkey. 